\title{
Niemann-Pick disease type B
}

INSERM

\section{Source}

INSERM. (1999). Orphanet: an online rare disease and orphan drug data base. NiemannPick disease type B. ORPHA:77293

Niemann-Pick disease type B is a mild subtype of Niemann-Pick disease, an autosomal recessive lysosomal disease, and is characterized clinically by onset in childhood with hepatosplenomegaly, growth retardation, and lung disorders such as infections and dyspnea 